\title{
Corbulo versus Vologases: A Game of Chess for Armenia
}

\author{
Leonardo Gregoratti
}

Durham University

\begin{abstract}
The available books of Tacitus' Annales constitute the most important source of information concerning the long war between Rome and the Great King for supremacy in Armenia. Leaving in the background the stereotypical way in which the Arsacids are often portrayed, his characterisation of the protagonists, both Roman and Parthian, reflects Tacitus' opinions about Rome' political past and present. The representations the Roman author provides of the various leaders, Corbulo, Paetus, Vologases and Tiridates, seem to marginalise the distinction between Roman and Parthians, in order to distinguish between those who are familiar with the rules of psychological warfare and experts in the tricks of the war game and those who are tragically not.
\end{abstract}

Keywords: Armenian Wars, Nero, Corbulo, Parthians, Vologases, Tacitus, Paetus, terror.

From the mid-first century BC, when the Roman legions led by the triumvir Crassus met their fate on the open steppes of northern Mesopotamia, to the early decades of the third century AD, the Parthians fiercely opposed Rome's expansionist goals in the East. ${ }^{1}$ A quick look at a map showing the extension of the Arsacid domains makes it clear that the Parthian Empire was a geographically imposing political subject, a fearsome opponent, due to its size and resources, for the state which considered itself the heir to the Greeks west of the Euphrates: that is to say Rome.

The invasion attempts from both sides that followed Carrhae, though exploiting the periods of political crisis in the respective empires, brought nothing more than ephemeral and inconclusive victories eventually followed by decisive defeats. ${ }^{2}$ The circumstances forced Augustus to settle once and for all the res in Oriente. Dismissing the majestic plans for another invasion put into action by his adoptive father, ${ }^{3}$ he arranged a meeting

1 On the Parthian empire: Debevoise 1938; Ziegler 1964; Schippmann 1980; Bivar 1983; Dąbrowa 1983; Frye 1984; Wolski 1993; Wiesehöfer 1994; Wiesehöfer 1998; Verstandig 2001 and the more recent Shayegan 2011 and Ellerbrock - Winkelmann 2012 ( $2^{\text {nd }}$ ed. 2015); Gregoratti 2017a; Gregoratti 2017b. For the sources concerning the history of the Parthian Kingdom, see the excellent Hackl - Jacobs - Weber 2010; on Carrhae: Traina 2010.

2 See Noè 1992; Engels 2008; van Wijlick 2015.

3 Malitz 1984; Buttrey 2015. 
on an island in the middle of the Euphrates between his adopted son Gaius Caesar and the Parthian King Phraates V. ${ }^{4}$

Before their armies, as admirably described by the young officer and eyewitness Velleius Paterculus, ${ }^{5}$ the delegates of the two rival powers, Rome and Parthia, marked the limits of the spheres of their political influence and divided the whole known world. Setting the boundary as the Euphrates, the leadership of the universal Roman state was de facto forced to admit a limit to its expansion, and therefore the existence of something beyond Rome - Parthia, a political subject which the successors of Alexander's greatness had not been able to reduce to obedience. ${ }^{6}$

As we know, Augustus was not only a skilled politician, but also, and above all, a sophisticated master of propaganda. Thus, as Charlotte Lerouge has shown, the Parthians began to be described as "the barbarians of the east," a people characterised by a whimsical and inconstant nature. They were politically unstable, because they were unfaithful, treacherous and unable to consolidate a kingdom always on the brink of collapse. The needs of imperial representation imposed such a stereotyped portrait of "the other": the Parthian state must not and could not be perceived as a political alternative. ${ }^{7}$

After the Euphrates meeting, the two superpowers competing for supremacy in Western Asia faced each other, keeping a watchful eye on the adversary, carefully studying their moves in order to be able to effectively counterstrike them, ready to exploit politically any weakness, any hesitation of "the other," like two boxers in a ring, or better, two grandmasters at a chessboard. ${ }^{8}$

An indirect conflict between Rome and Parthia then took place. A war fought through diplomatic missions, ambassadors and negotiations, pretenders to the Arsacid throne and Roman financial support to internal opponents, which stretched until $51 \mathrm{AD}$, when a new energetic Arsacid, Vologases I, became the Great King. ${ }^{9}$ By associating his two brothers, monarchs in Armenia and Media Atropatenes, with the throne, he conferred stability to the top of the state structure, refunding and consolidating the whole Parthian empire. ${ }^{10}$

The kingdom of Armenia, at that time ruled by Mithridates, a member of the Iberian royal house put on the throne by the Romans, constituted one of the pillars of Vologases' plans for the renaissance of the Parthian Empire. Between 53 and 54 AD, Rhadamistos, Mithridates' nephew, with the connivance of his father Farasmenes, the Iberian ruler, staged a coup d'état, killed his uncle and seized the throne illegally. ${ }^{11}$

4 Cass. Dio, LV, 10.18-19; Suet., Tib., 12.2; Oros., Adv. Pag., VII, 3.4; Romer 1974, 171-173; Greatrex 2007, 151-153; Luther 2010, 103-127; Edwell 2013, 201.

5 Vell. Pat. II, 101.2-3; Quod spectaculum stantis ex diverso hinc Romani, illinc Parthorum exercitus, cum duo inter se eminentissima imperiorum et hominum coirent capita [...] mihi visere contigit.

${ }^{6}$ Gregoratti 2015a, 738.

7 Lerouge 2007; Gregoratti 2012a.

8 For Augustus' policy, apart from the abovementioned general works see: Oltramare 1938; Zetzel 1970; Krämer 1973; Romer 1979; Timpe 1975; Barzanò 1985; Wiesehöfer 2010; Schulde 2015. For the JulioClaudian dynasty: Flav. Ioseph., Ant. Iud., XVIII, 46; 96-97; 100-104; Tac., Ann., II, 1-3; 43; 56; VI, 2-3; 31-38 and 41-42; XII, 10-14; Cass. Dio, XL, 15; LVIII, 26; Pani 1972, 20-61; Chaumont 1976, 74-90; Angeli Bertinelli 1979, 45-59.

9 Sellwood 1980: S 68-72, 223-224, 231-234; Olbrycht 1998a, 125; Karras-Klapproth 1988, 192-199; Sinisi 2012, 138-148, notes 451-495; Olbrycht 2016, 217-218.

${ }_{10}$ Gregoratti 2015b, 208; Gregoratti 2016, 87-88.

11 Tac., Ann., XII, 44-51; Braund 1994, 221-224. 
The revolt of the Armenian subjects against a foreign and illegitimate ${ }^{12}$ monarch and the subsequent power void provided Vologases with the pretext he needed to intervene and take control of the kingdom in favour of his younger brother, Tiridates. ${ }^{13}$ Nobody in his family was to remain without a throne. ${ }^{14}$

In the same months, at Rome anxiety and expectation were quickly growing around the new ruler of the vast Roman Empire. This 17-year-old boy was destined to be remembered as one of the most infamous emperors of all time: Nero. ${ }^{15}$

A military reaction to the facts in Armenia was considered by everybody to be necessary and beyond discussion. ${ }^{16}$ The concern in Rome focused rather on whether or not such a young princeps would be able to lead the empire in a direct clash against its powerful eastern enemy. The influence on the boy of his tutors, Burrus and Seneca, was evident to all. ${ }^{17}$ The dilemma was: would it be possible to undertake through the tutors the battles, the sieges and all that was needed to conduct a successful war on the field? ${ }^{18}$

In Book XIII of his Annales, Tacitus voices the doubts and the "chatter" of the Romans on the eve of a war considered imminent, unavoidable and necessary. In the following lines, however, the same author seals the debate on the question: "The highest rank chiefly worked through its prestige and its counsels more than by the sword and hand" (pleraque in summa fortuna auspiciis and consiliis quam telis and manibus geri).$^{19}$ Nero, as emperor, was of course not required to go into the field and lead his armies: a good policy, good advisors and good strategy can do more to win a war than battles and the clash of weapons.

In my opinion, these are revealing words. In less than one line, Tacitus, about to narrate the imminent conflict in detail, wants to give the reader in advance the key to understanding the personality of the man chosen as commander in chief, the hero of his narrative, Gn. Domitius Corbulo, and to interpret the philosophy that the general will be able to apply to the entire conflict. It seems that Tacitus wants to prepare his reader for a conflict which, according to his narrative, presents most of the characteristics of the preceding period of political, non-military confrontation, one which would have appeared rather unusual from this perspective, especially if compared to Trajan's resolute way of conducting the recent war in the east, events with which all Romans were familiar. ${ }^{20}$

Tacitus is about to narrate a sort of drôle de guerre, which stretched slowly and wearily over many years, where peace negotiations, tactical stratagems, ruses, but also appearance, the ability to impress, and psychological factors in general, seemed to influence the course of events and achieve prominence in the narrative more than the mere facts of arms. A war in which prestige and counsels did more than the sword and the hand.

\footnotetext{
12 Tac., Ann., XII, 50.1: a maioribus suis possessam externus res flagitio obtineret.

13 Tac., Ann., XII, 44.

14 Tac., Ann., XII, 50.1: ne qua pars domus sine imperio ageret.

15 Tac., Ann., XIII, 6.2-4.

16 Oller Guzmán 2014, 85-86.

17 Tac., Ann., XIII, 6.3.

18 Tac., Ann., XIII, 6.2.

19 Tac., Ann., XIII, 6.4.

${ }^{20}$ Syme 1958, 465-480.
} 
Although only few books of Tacitus' Annales survived, his work still constitutes the most important source of information concerning Parthia and the Arsacid kings during the first century AD, and in particular regarding the long war for supremacy in Armenia.

The second-century historian (he probably wrote the Annales in the $20 \mathrm{~s}^{21}$ ) was born in $56 \mathrm{AD}$, and was therefore only a child when the Roman-Parthian war broke out. ${ }^{22}$ He took his steps in the Roman administration under Vespasian, who had taken Nero's place after he was overthrown, and founded a new dynasty. He advanced steadily through the cursus honorum under the Flavians, experiencing the tyranny of Domitian, Vespasian's second son and emperor. He witnessed the fall of that second tyrant, the rise of Trajan, the failure of his campaign and conquest plans for the east, as well as the discussed and criticised restoration of the eastern frontier operated by his successor Hadrian. $^{23}$

As modern scholars generally agree, all his historical work represents a collection of his experiences concerning Roman emperors and their policies and behaviour. It is a warning, a sort of historical will, against the dangers of despotism and the degeneration of the principate into tyranny, and against the excesses that occur when decisions are taken by one powerful man alone.

All his portraits of Parthian Great Kings, both positive and negative, are more or less coherent with this concept. ${ }^{24}$ The nature of the oriental people in Tacitus' work in fact does not seem to differ from the usual stereotypes employed by other authors, as evident, for example, from the words put into the mouth of Caius Cassius, governor of Syria, commissioned to escort the young prince Meherdates, a pretender to the Arsacid throne, to the banks of the Euphrates. He "reminded Meherdates that the impulsive enthusiasm of barbarians soon flags from delay or even changes into treachery, and that therefore he should urge on his enterprise." ${ }^{25}$ In fact, in the course of that campaign in the east, many Parthian vassal lords deserted with their troops, "with their countrymen's characteristic fickleness," writes Tacitus, "confirming previous experience, that barbarians prefer to seek a king from Rome than to keep him."26

On the other hand, regarding the oriental kings and the Arsacid royal personalities, the main characters of his history, Tacitus used elements taken directly from the common prejudicial and propagandistic descriptions only when it was instrumental in order to better explain his criticisms of the Roman leadership, past and present.

Thus King Artabanus, ${ }^{27}$ Great King in the first half of the first century AD, is an arrogant man, ambitious towards Rome and cruel towards his subjects. He is depicted as a sort of anti-Hellenised ruler, a "Scythian," the youngest and cruellest people in antiquity according to Herodotus, ${ }^{28}$ a merciless tyrant who could threaten the Roman supremacy in the area only because an old and weak Tiberius was leading the Roman Empire at that

${ }^{21}$ Syme 1958, 768-770; Potter 1991.

22 Syme 1958, 63-64.

${ }_{23}$ HA Hadr. 5 and 9; Heil 1997, 109, 140-141; Vervaet 1999a, 292-296. For Tacitus' approval of Corbulos' policy in the east in opposition with Trajan's one: Delpuech 1974, contra Gallotta 1978.

${ }^{24}$ Gregoratti, forthcoming.

${ }_{25}$ Tac., Ann., XII, 12.2.

${ }^{26}$ Tac., Ann., XII, 14.

${ }^{27}$ Olbrycht 2012.

${ }^{28}$ Hdt., Hist., IV, 5. 
time. ${ }^{29}$ Furthermore, in Rome, Claudius was showing very little interest in ruling the empire directly. Rome's chances of exploiting the strife between the kings who came after him - Gotarzes, the cruel kingslayer ${ }^{30}$ and Vardanes, the Arsacid "Alexander," 31 hated by his subjects - were therefore entrusted only to some young and inexperienced Parthian prince thrown into the fray.

The same political quiescence from the Roman authority led to the emergence of the troubles in Armenia. The truculens Rhadamistus assumed power illegally, ${ }^{32}$ opposed, in the absence of a Roman intervention, only by the Parthian Great King Vologases and his brother Tiridates. Descendants of a Greek concubine, ${ }^{33}$ they are immediately shown in a different light: the political plans of Vologases aim at helping the Armenians to get rid of the hated and foreign sovereign and are dictated by the will and the need to share his power, rather than by mere thirst for conquest. ${ }^{34}$ Furthermore, the episode of Queen Zenobia, Rhadamistus' wife, mercilessly stabbed and thrown into the river by her husband, before being rescued and honoured by her enemy Tiridates, clearly marks the difference between the pair of Arsacid monarchs and the ruthless oriental kings who preceded them. ${ }^{35}$

Returning to Tacitus' narrative, probably thanks to Seneca's influence on Nero, ad Armeniam retinendam, ${ }^{36}$ the illustrious general Gn. Domitius Corbulo was chosen. He was a veteran of the fields of Germany, ${ }^{37}$ where he had already found glory, and Tacitus' tragic hero. ${ }^{38}$ The historian considers this appointment as an acknowledgment of evident and indisputable merits and valour, an example of good rule by a monarch guided by wise counsellors. ${ }^{39}$

Immediately upon arrival in the East, endowed with the special and brand new command over the joined Cappadocia and Galatia, ${ }^{40}$ like every charismatic leader (and some of the most famous chess players, to refer to the metaphor in the title), Corbulo began to build on his fame and reputation with the purpose of creating a sort of "myth" around himself. His actions as undisputed leader clearly aimed at impressing.

Due to his reputation, with the sympathies of the soldiers and allied kings all heavily on his side, ${ }^{41}$ "anxious to strengthen that personal credit which is of supreme importance at the beginning of an enterprise," 42 as Tacitus explains, he tried to enter Syria to take control of his troops. He was prevented from doing so by the Syrian governor,

29 Tac., Ann., II, 3; VI, 36; 41-42; Kahrstedt 1950, 11, 14 and 66; Schottky 1991, 63-69; Olbrycht 1998b, 139-140; Gregoratti 2012c; Olbrycht 2014, 92-97; Gregoratti 2015b; Gregoratti 2015c.

30 Tac., Ann., XI, 8. 2; Chaumont 1979, 162-164; Olbrycht 1997, 82-85; Olbrycht 1998b, 157-163, 172.

31 Tac., Ann., XI, 10.2.

32 Tac., Ann., XII, 47; 50.2; 51.1-3.

33 Tac., Ann., XII, 44.2.

34 Tac., Ann., XII, 50.1.

35 Tac., Ann., XII, 51.

36 Tac., Ann., XIII, 8.1.

37 Tac., Ann., XI, 18-20; Cass. Dio, LX, 30.4-6; Hammond 1934, 87; Syme 1970, 38; Mehl 1979; Vervaet $1999 \mathrm{~b}, 587-598$.

38 PIR² D 142; Syme 1970, 27-31; Chaumont 1976, 98-101; Dąbrowa 1989, 70; Vervaet 1999b, 587-598.

39 Tac., Ann., XIII, 8.1: videbatur locus virtutibus patefactus.

40 Until the autumn of 60 AD: Vervaet 1999b, 578-581.

41 Tac., Ann., XIII, 8.2.

42 Tac., Ann., XIII, 8.3. 
Quadratus, ${ }^{43}$ who rushed to meet him in Cilicia, fearing that once he entered his province all attention would be on him, not only due to his solid and extraordinary reputation, but also to his oratory skills and good looks. ${ }^{44}$

Corbulo was, of course, aware of his reputation and qualities - those essential for a military leader, experience and sagacity, as well as the inanes, the inessential ones, his appearance and eloquence. All these elements merge into Corbulo's figure, or rather into Tacitus' description of his "hero" Corbulo, to provide the image of a man well above his contemporaries. To this characterisation, Tacitus adds unscrupulous behaviour towards the other Roman officers: Corbulo plans to make a triumphant entrance to Syria, Quadratus' province, and later seizes the Parthian hostages Quadratus had managed to obtain from Vologases. ${ }^{45}$

Corbulo entered the near eastern scene with the purpose of impressing the other actors, all other actors, Roman and non-Roman. Quadratus, formally not inferior to Corbulo, ${ }^{46}$ was the first victim of this attitude, overwhelmed by his lumbering colleague, he quickly disappeared from Tacitus' narrative. The hostages episode contains some interesting elements for reflection. The unavoidable quarrel between the two officers was resolved by the Parthian hostages' predictable preference for the celebrated Corbulo. ${ }^{47}$ This fact demonstrates that Corbulo's strategy was meant to impress not only Roman officers, placing them under a sort of psychological subjection, but also, and possibly above all, the enemy on the other side of the Euphrates. The Parthians, who surely knew who Corbulo was, also seem to be affected by the general's character and appearance.

Corbulo's justifications in response to Quadratus' complaints seem to confirm this reconstruction: "the king (Vologases) had been converted to the course of offering hostages, only when his own appointment as commander in the field changes his hopes into alarm." ${ }^{48}$ Of course, the Syrian governor was in the right, and Corbulo's words are an expression of his arrogance; nonetheless, what Tacitus has him say is revealing.

The word used is metus, fear, anxiety - the first instance of many to come (in the narrative of the Armenian conflict), as we shall see, in which Tacitus employs a word belonging to the semantic sphere of terror. Vologases has been placed in fear by Corbulo's arrival. Of course this was not true, but sheds light on the psychological aspects of Corbulo's role and strategy in the east: instilling fear and apprehension is part of a strategy that can win wars.

The Roman troops in the East were unprepared for war; the Great King was involved in quashing the unexpected revolt of the fiulius Vardanis, and unable to support his brother's forces in Armenia. ${ }^{49}$ Thus the drôle de guerre, which was the Armenian conflict, began immediately with hectic diplomatic activity. Corbulo's butade suggests that in a conflict fought through consilia and magnifica verba, instead of telis and manibus

\footnotetext{
43 On C. Ummidius Quadratus: Syme 1968, 73-75.

44 Tac., Ann., XIII, 8. 3: corpore ingens, verbis magnificis; Gilmartin 1973, 587-589; Ash 2006, 364-366.

45 Tac., Ann., XIII, 9.1-2.

46 Hammond 1934, 88-92.

47 Tac., Ann., XIII, 9.2.

48 Tac., Ann., XIII, 8.3.

49 Tac., Ann., XIII, 7.2; Schottky 1991, 117-119.
} 
("with the sword and the strong arms"50), the ability to impress and deceive the opponent was much more effective than mere military or political activity.

A different game seems to take shape through Tacitus' narrative, a much subtler one than Trajan's strategy of direct conquest, a game constructed from stratagems and wellmeditated moves and countermoves, on and off the field.

Once on the frontline, Corbulo's first move consisted in preparing his army for war. He trained his soldiers, softened by many years of comfortable service in the Eastern cities, through hard marches, winter camps and tough punishments, and not forgetting to inspire his troops with his own example. He recruited new soldiers and integrated his legions with units from Germany. In a word, he did all that was necessary to deploy a fearsome army in the field, an effective means for a general to both win battles and impress the enemy. ${ }^{51}$

The context is better outlined by the continuation of the narrative. Corbulo's idea of using the troops as an effective deterrent, and not as an attacking force, is shown by the orders dispatched preventing his officers from engaging with the enemy. An inexperienced officer, Paccius Orfitus, convinced, probably by what has been shown to him, ${ }^{52}$ that the enemy is defenceless, decided to attack and was badly defeated, probably falling into a trap..$^{53}$ The defeat spread terror through the Roman army (damno exterriti ${ }^{54}$ ). Following this success, Tiridates began to ravage Armenia. His highly mobile tactics, comprising of sudden attacks and rapid runs, eluding contact, says Tacitus, were intended "to disseminate terror (exterrere) due more to rumour than to the sword." ${ }^{55}$

These two episodes show that also on the other side of the Euphrates, Corbulo's strategy based on fear and impression was not only known, but also successfully employed. The idea sketched out is that of a sort of psychological warfare taking place between Corbulo and the Parthian kings, an integral part of both the military and diplomatic confrontation. A strategy that employed various alternative means to achieve the maximum effect on the enemy strategy was deeply rooted and particularly suited to the nature of the Armenian conflict.

Tacitus' account continues. The Hyrcanian revolt in the East again forced Vologases and Tiridates into negotiations (58 AD).$^{56}$ The young prince proposed a meeting between the two leaders: Corbulo was allowed to bring as many soldiers as he wanted as an escort, provided their helmets and cuirasses were removed. ${ }^{57}$ The experienced leader, infers Tacitus, immediately understood the trick - Roman soldiers without body protection would be torn to pieces by Parthian bowmen, no matter their number ${ }^{58}$ - but he pretended not to, and proposed to meet in the presence of the whole armies. He then chose a meeting place where the terrain was suitable for infantry tactics, merged the sixth and

${ }^{50}$ Tac., Ann., XIII, 6.4.

51 Tac., Ann., XIII, 35; Henderson 1901, 205-206, 209-210, 266-274; Asdourian 1911, 89; Schur 1925,

75-96; Grosso 1957, 187-189; Gilmartin 1973, 597; Chaumont 1976, 100; Wheeler 1997, 383-385, 392-397.

52 Tac., Ann., XIII, 36.2.

53 Tac., Ann., XIII, 36; Gilmartin 1973, 593-597.

54 Tac., Ann., XIII, 36.2.

55 Tac., Ann., XIII, 37.1: plura fama quam pugna exterrere.

56 Tac., Ann., XIII, 37.5.

57 Tac., Ann., XIII, 38.1.

58 Tac., Ann., XIII, 38.2. 
the third legions together with only one aquila, to look like a single legion. For his part, Tiridates stopped at a distance in a place where he could be seen by everybody, but not heard. He was there, and made sure that everybody noticed him, but he stopped too far away for the meeting to effectively take place. ${ }^{59}$

During the subsequent invasion of Armenia (58-59 AD) ${ }^{60}$ when very limited actual fighting took place, the key to the confrontation does not seem to change. On the one side, Tiridates tried to reemploy on the Roman marching army the deceptive tactics successfully used to induce Orfitus into a trap, but the presence of the skilled and experienced general nullified his efforts. ${ }^{61}$ On the other, Corbulo's military actions seem to target the Armenians more than his rival: ${ }^{62}$ he took the castellum of Volandum, slaughtering all the defendants and selling all the others as slaves. ${ }^{63}$ The terror he was again able to inspire in the enemy caused the capitulation first of the other fortresses, then of the capital Artaxata itself. The terror is further increased by the destruction of the just occupied city, a decision taken mainly for military reasons. ${ }^{64}$ As Tacitus explains, the city in fact could not be held due to its size, but was cunningly used by Corbulo to achieve further successes: "after razing Artaxata, Corbulo resolved to profit by the first impression of terror in order to seize Tigranocerta." ${ }^{\prime 65}$ Envoys from the capital in fact followed immediately, bringing news that Tigranocerta's city gates were open and their countrymen awaiting his orders. This was another success Corbulo achieved without fighting. ${ }^{66}$

In Tacitus' narrative, both rivals seem to be playing a game, seeming to share the knowledge of its rules, unlike the other minor, less experienced actors. The protagonists of Tacitus' history, Corbulo and the young Arsacid, seem to be bound together like in an initiatory circle, a club whose members are skilled in the art of conducting a war through deception, terror, appearance and psychology, more often than through bravery and weapons. The distinction between Roman and oriental enemies seems to blur in the face of this duel between the leaders.

This last circumstance appears much more evident once Tacitus introduces new characters; things in the east being settled, Vologases is ready to take the place of his brother, who, though skilled, was no longer a match for Corbulo, and led the war. ${ }^{67}$

After the conquest, Nero, who got rid of Seneca's positive influence and whose rule was quickly acquiring the characteristics of a tyranny, chose to place one of his minions on the Armenian throne. This was Tigranes, a hostage of Cappadocian origin, considered by the Parthians in the same way as a slave. ${ }^{68}$ Tigranes invaded the prestigious Parthian kingdom of Adiabene, forcing Monobazos, the monarch, to seek refuge in Parthia. He collaborated

59 Tac., Ann., XIII, 38.3-4.

60 Tac., Ann., XIII, 39-41; XIV, 24-25; Cass. Dio, LXII, 19-20; Frontin., Strat., II, 9.5; IV, 1.21 e 28 ; Henderson 1901, 210-212; Schur 1923, 89-93; Schur 1925, 7-12; Schur 1926, 215-222; Gilmartin 1973, 594-599; Chaumont 1976, 104-107; Wheeler 1997, 386-392.

61 Tac., Ann., XIII, 40.

62 Gregoratti 2012b.

63 Tac., Ann., XIII, 39.

${ }^{64}$ Tac., Ann., XIII, 41.1-2.

65 Tac., Ann., XIV, 23.1.

66 Tac., Ann., XIV, 24.4; Traina 1996, 492-493.

67 Tac., Ann., XV, 1.1.

68 Tac., Ann., XIV, 26. 
with Tiridates, Vologases' brother and former king of Armenia, driven off from his throne by the Romans, to denounce the situation before the Parthian court, accusing Vologases of failing in his feudal duties and not doing enough to protect his subject kings' thrones. ${ }^{69}$

The accusation was serious, and threatened to ruin the trust between the Great King and his subjects, ruining the entire structure of government conceived by Vologases. Tacitus portrays him as an "enlightened King," a wise and just ruler, reluctant to go to war and ready to share his power and gather his subordinates to witness and ratify his decisions. In contrast to what was going on in Rome in the same years, Vologases summoned the restricted council, heard the different opinions and took the painful decision to resume the conflict.

Circumstances forced the Great King to react, but his scarce enthusiasm brought scant results. Parthian troops soon found themselves bogged down in the hopeless siege of Tigranocerta, while on the Euphrates Corbulo was blocking the way after having instructed his officers not to engage the enemy in battle. ${ }^{70}$

Tacitus informs us that the Roman general, now in command of the whole Near Eastern theatre of war, ${ }^{71}$ preferred once again to avoid overt war in order not to compromise the glory already achieved. On the other side, Vologases, who was always keener to negotiate than fight, was interested in gaining time through diplomatic activity, in the hope that sooner or later another commander in chief, surely less fearsome than Corbulo, would be appointed. ${ }^{72}$

In fact, Tigranes was not the worst appointment made by the tyrant Nero. L. Caesennius Paetus was appointed as governor of Cappadocia-Galatia and commander in chief of operations in Armenia. ${ }^{73}$ Once arrived, he showed no reticence in publicly and disdainfully denouncing the way his illustrious colleague, now governor of Syria, ${ }^{74}$ had conducted the war until then. No enemy blood was shed, nor booty taken, and in his opinion cities had been conquered only nominally. It was up to him now to impose Roman law and rule on the Armenians, instead of an evanescent king. ${ }^{75}$

It seems clear that Tacitus considered Paetus to be an expression of Nero's autocracy, a minor manifestation of his master's vices and the best proof of the risks of such a form of government. Nonetheless, it is impossible, as it certainly was for Tacitus' readers, ${ }^{76}$ not to note the clear reference to Trajan's campaign in Paetus' claim about Armenia. These words are a striking echo of Trajan's speech at Elegeia, ${ }^{77}$ where, before his troops and a disconcerted Parthamasiris, the Arsacid king of Armenia, the optimus princeps publicly revealed his plan for the annexation of the contended kingdom.

69 Tac., Ann., XV, 1.2-4; 2; Cass. Dio, LXII, 20.2; Hammond 1934, 92; Gilmartin 1973, 605-607; Chaumont 1976, 107-109; Gregoratti 2015b. For Anna Clark (2011, 208-231), the entire episode of the council meeting is an invention.

70 Tac., Ann., XV, 4-5; Cass. Dio, LXII, 20.2-4; Hammond 1934, 92-94; Chaumont 1976, $109-111$.

71 After Quadratus' death until Paetus' arrival in 61 AD.

72 Tac., Ann., XV, 6.2-3.

73 From the autumn of 62 to the winter of 63 AD: Hammond 1934, 94; Salvo 2008/2009, 230-231. Earlier for Heil 1997, 216-220 and Carter 2004. For his career under the Flavians, see Garzetti 1966.

74 Vervaet 1999b, 596-597.

75 Tac., Ann., XV, 6.4.

76 Vervaet 1999a, 291-292; Vervaet 2002, 303-312.

77 Cass. Dio, LXVIII, 19-20; Eutr., Brev., VIII, 3.1; Momigliano 1975, 654-655. 
What the main protagonists, Corbulo and Tiridates, had done until that moment, and all that the reader has learnt about Armenian wars and has become familiar with, is now put irremediably into discussion by Paetus' figure and activity.

Paetus, with his winter quarters still inadequately protected, rushed forward deep into Armenia, looking for battle, neglecting to ensure his supply lines, ignoring the effective strength of his troops, dispersing his forces and refusing to listen to the advice of more expert officers. ${ }^{78}$ Apart from the evident lack of basic military skills, the difference to Corbulo's and the Parthians' cautious approach to war is striking. Tacitus enforces the dichotomy, describing in detail the progressive operations put into action by the senior general on the Euphrates: having established presidia on the western bank, he used large barges to ensure protection to the soldiers who were building a bridge over the river. Later, the bridgeheads were established, and the barbarians dislodged from the eastern bank. ${ }^{79}$

Paetus' lack of military skills and arrogance, not to mention his disdain for omens, ${ }^{80}$ however calamitous they were in such a situation, did not constitute the main reason for his fall. After launching a first campaign into enemy territory and conquering several fortified places which he was unable to keep for long, before the coming of the winter he dared to send the emperor a letter in which he magnified his feats. ${ }^{81}$ In the following year, determined to launch a new aggressive campaign, he again led the legions into the field, declaring that "not moat or rampart but men and arms were the means assigned him for dealing with a foe." $\$ 2$ This statement, like the previous letter describing his amazing victories to Caesar, revealed itself to be full of verba magnifica, vacuum rerum: "grandiloquently phrased, but void of content." ${ }^{83}$ The loss of a centurion and few soldiers he had sent ahead to inspect the enemy's force in fact caused trepidation in the governor, determining the withdrawal of his troops. ${ }^{84}$

This, according to Tacitus, seems to be the real weakness of Paetus: his incapacity to show decisiveness ${ }^{85}$ in pursuing his goals and his tendency to lose his head even in minor adversity. In a conflict where the psychological factor played a fundamental role, as we have seen this could be a serious vulnerability a skilled opponent could easily spot and take advantage of.

Vologases was an experienced player. He seems to have immediately become aware of the weak point in the Roman front, and therefore increased the pressure on Paetus. ${ }^{86}$ Soon, the first serious setbacks knocked the young general's self-confidence. Survivors, runaways and wounded began to storm the rear lines in the grip of fear, spreading astonishing news about the Great King's bravery and brutality. These tales found fertile ground among soldiers already stricken by terror, ${ }^{87}$ and also shocked the commander,

\footnotetext{
78 Tac., Ann., XV, 7-8; Gilmartin 1973, 611-612.

79 Tac., Ann., XV, 9.

80 Tac., Ann., XV, 7.2; 8.1; Meulder 1993, 98-99.

81 Tac., Ann., XV, 8.2.

${ }^{82}$ Tac., Ann., XV, 10.2: non fossam neque vallum sibi, sed corpora et arma in hostem data.

83 Tac., Ann., XV, 8.2.

84 Tac., Ann., XV, 10.2: trepidatus.

85 Tac., Ann., XV, 10.1.

86 Tac., Ann., XV, 11.

87 Tac., Ann., XV, 11.2.
} 
who, as Tacitus states explicitly, was unable to face adversity. ${ }^{88}$ The request for help that reached Corbulo on his slow march to rescue him highlights Paetus' desperation. ${ }^{89} \mathrm{He}$ implored Corbulo to hurry to save the standards, the aquilae and the name of the Roman army; as for him, he would have fought on until death.

Paetus is clearly succumbing to panic at this point. Unable to fight back, his desperation and incompetence were mirrored by his troops, who, quickly broken by the enemy's assaults, began to speak openly of surrender. ${ }^{90}$ Having lost all his will to fight, Paetus asked for negotiations and surrendered to the enemy. ${ }^{91}$

With the Roman defeat, Tacitus' narrative of the Armenian wars soon reaches its climax. All the detailed accounts of the confrontation between Corbulo and the Parthians, all the work done, the successes achieved, all is lost due to the arrogance of a man who refused to pay respect to wiser and more experienced soldiers, a man outside the circle of the experienced players, who refused the rules of the game, thus becoming the most illustrious victim of the game itself.

Corbulo's hesitation to collaborate with him $^{92}$ marks the distance between the two rivals, but also the insuperable isolation of a man who has no means, or refuses, to understand a series of unwritten values and laws about war, laws that managed to associate even those, like Corbulo and Vologases, who belonged to different worlds and were enemies on the field.

Like every good story, Tacitus' one too needs a coup de théâtre: "For the rest, it is established that the beleaguered forces were so well supplied with corn that they set fire to their granaries; while, on the other hand, [...] the Parthians were on the point of raising the siege through the scarcity of supplies and the dwindling of the forage." ${ }^{\prime \prime}$

The information is attributed to Corbulo, probably taken from the commentarii written by the general ${ }^{94}$ or from the reports he sent to Rome after the defeat. Tacitus presents the possibility that these details were invented by Corbulo himself in order to further discredit Paetus in the eyes of the Roman leadership. ${ }^{95}$

True or not, this reference fits perfectly into Tacitus' narrative about the war, at the same time constituting an excellent epilogue to the game that took place for Armenia.

Corbulo's report after Tacitus' narrative of the Armenian defeat reveals the true or supposed background of its climactic event, proving that Vologases, who was obviously not given as much attention as Corbulo, was a master in the game of dissimulation and appearance. He was as skilled as the Roman general in the art of appearing stronger and instilling terror, that is to say in the art of psychological warfare. These remarks concerning the actual weakness of the Parthians in opposition to Paetus' superior capacity to hold his positions for a long period show to the reader how powerful and effective the ability to impress the opponent and manipulate reality could be. These skills can win a war as much as "the sword and the hand."

\footnotetext{
${ }^{88}$ Tac., Ann., XV, 11.3: ne dux quidem obniti adversis.

89 Tac., Ann., XV, 11.3.

90 Tac., Ann., XV, 13.

91 Tac., Ann., XV, 13-14.

92 Tac., Ann., XV, 17.

93 Tac., Ann., XV, 16.1.

94 Questa 1960; Traina 1996, 491.

95 Tac., Ann., XV, 16. 3.
} 
These post-defeat remarks reveal the nature of Vologases' strategy and the kind of game he was playing, the same as Corbulo and, on a lower level, Tiridates. Paetus is not part of that circle to which all the other major actors seem to belong; he is the odd one out. He was the victim of a subtle game he was not able to understand. With his weak nature, he never stood a chance in that group of experienced and talented chess players. His incapacity to maintain control and his inability to distinguish reality from appearance made him the perfect victim of the game. Led to believe that the situation was much more desperate than it actually was, he lost his head. Vologases did not defeat Paetus; Paetus' own terror and despair did.

As Bobby Fischer put it: "Chess is war over the board. The object is to crush the opponents' mind." 96

BIBLIOGRAPHY

Angeli Bertinelli, M.G. (1979), Roma e l'Oriente. Strategia, economia, società e cultura nelle relazioni politiche fra Roma, la Giudea e l'Iran, Roma.

Asdourian, P. (1911), Die politischen Beziehungen zwischen Armenien und Rom von 190 v. Chr. bis 428 n. Chr., Freiburg i. d. Schweiz.

Ash, R. (2006), Following in the Footsteps of Lucullus Tacitus's Characterisation of Corbulo, Arethusa 39: $355-375$.

Barzanò, A. (1985), Roma e i Parti tra pace e guerra fredda nel I secolo dell'impero, in: M. Sordi (a cura di), La pace nel mondo antico, Milano: 211-222.

Bivar, D.A. (1983), The Political History of Iran under the Arsacids, in: E. Yarshater (ed.), The Cambridge History of Iran, vol. III, pt. 1: The Seleucid, Parthian and Sasanian Periods, Cambridge: 21-99.

Braund, D. (1994), Georgia in Antiquity: A History of Colchis and Transcaucasian Iberia 550 BC-AD 562 , Oxford.

Buttrey, T.V. (2015), Caesar at Play: Some Preparations for the Parthian Campaign, 44 BCE, Journal of Ancient History 3: 220-241.

Carter, M. (2004), The "Lex Portorii" and the Armenian Campaign of Caesennius Paetus, Latomus 63: 370-379.

Chaumont, M.-L. (1976), L'Arménie entre Rome et l'Iran, I: De l'avènement d'Auguste à l'avénement de Dioclétien, $A N R W$ II, 9, 1: 71-194.

Chaumont, M.-L. (1979), Études d'histoire parthe IV. A propos d'une inscription du "Grand Roi” Gotarze, Syria 56: 162-164.

Clark, A. (2011), Vologaeses as Mirror, Histos 5: 208-231.

Dąbrowa, E. (1983), La politique de l'état parthe à l'égard de Rome-d'Artaban II à Vologèse I (ca $11-c a 79$ de n. è.) et les facteurs qui la conditionnaient, Kraków.

Dąbrowa, E. (1989), Roman Policy in Transcaucasia from Pompey to Domitian, in: D. French, C.S. Lightfoot (eds.), The Eastern Frontier of the Roman Empire. Proceedings of a Colloquium held at Ankara in September 1988, Oxford: 67-76.

Debevoise, N.C. (1938), A Political History of Parthia, Chicago.

\footnotetext{
96 Shenk 2007.
} 
Delpuech, P. (1974), Entre l'offensive et la démission. Corbulon et l'impérialisme tacitéen, in: L'ideologie de l'imperialisme romain, Colloque organisé les 18 et 19 octobre par la section latine de la Faculté des Lettres, Paris: 91-107.

Edwell, P. (2013), The Euphrates as a Boundary between Rome and Parthia in the Late Republic and Early Empire, Antichton 47: 191-206.

Ellerbrock, U., Winkelmann, S. (2012), Die Parther. Die vergessene Grossmacht, Darmstadt-Mainz.

Engels, D. (2008), Cicéron comme proconsul en Cilicie et la guerre contre les Parthes, Revue belge de philologie et d'histoire 86, 23-45.

Frye, R.N. (1984), The History of Ancient Iran, München.

Gallotta, B. (1978), Cn. Domizio Corbulone, Rendiconti / Istituto Lombardo, Accademia di Scienze e Lettere, Classe di Lettere, Scienze morali e storiche 112: 305-317.

Garzetti, A. (1966), L. Cesennio Peto e la rivalutazione flaviana di personaggi neroniani, in: R. Chevallier (éd.), Mélanges d'archèologie et d'histoire offerts à André Piganiol, vol. II, Paris: 777-790.

Gilmartin, K. (1973), Corbulo's Campaigns in the East: An Analysis of Tacitus' Account, Historia 22: 583-626.

Greatrex, G. (2007), Roman Frontiers and Foreign Policy in the East, in: R. Alston, S. Lieu (eds.), Aspects of the Roman Near East: Papers in Honour of Professor Fergus Millar FBA, Turnhout: $103-173$.

Gregoratti, L. (2012a), Parthian Women in Flavius Josephus, in: M. Hirschberger (ed.), Jüdisch-hellenistische Literatur in ihrem interkulturellen Kontext. Akten der Tagung, Düsseldorf, 10.-11. Februar 2011, Frankfurt: 183-192.

Gregoratti, L. (2012b), Between Rome and Ctesiphon: The Problem of Ruling Armenia, in: I.V. Ivanov et al. (eds.), Proceedings of the Conference Armenia -Iran: History. Culture. The Modern Perspectives of Progress, June 28, 2010, Moscow: 134-140.

Gregoratti, L. (2012c), The Importance of the Mint of Seleucia on the Tigris in the Arsacid History, Mesopotamia 47: 129-136.

Gregoratti, L. (2015a), In the Land West of the Euphrates: The Parthians in the Roman Empire, in: P. Militello, H. Oniz (eds.), Proceedings of the 15th Symposium on Mediterranean Archaeology, held at the University of Catania, March 3-5th, 2011, vol. II, Oxford: 731-735.

Gregoratti, L. (2015b), A Tale of Two Great Kings: Artabanus and Vologaeses, in: A. Krasnowolska, R. Rusek-Kowalska (eds.), Studies on the Iranian World, vol. 1: Before Islam, Kraków: 203-210.

Gregoratti, L. (2015c), The Kings of Parthia and Persia: Some Considerations on the "Iranic" Identity in the Parthian Empire, Dabir 1: 14-16.

Gregoratti, L. (2016), Legendary and Real Wealth in the Arsacid Kingdom, in: F. Santangelo, E. Bissa (eds.), Studies on Wealth in the Ancient World, London: 83-92.

Gregoratti, L. (2017a), The Arsacid Empire, in: T. Daryaee (ed.), King of the Seven Climes. A History of the Ancient Iran World (3000 BC-651 CE), Irvine, CA: 125-153.

Gregoratti, L. (2017b), Sinews of the other Empire: Parthian King's Rule over Vassal Kingdoms, in: H. Teigen, E. Seland (eds.), Sinews of the Empire: Networks in the Roman Near East and Beyond, Oxford: $95-104$.

Gregoratti, L. (forthcoming), Tacitus and the Great Kings, in: Iran and the West: Converging Perspectives, London.

Grosso, F. (1957), Mosè di Corene e Corbulone, La Parola del Passato 12: 177-191.

Hack1, U., Jacobs, B., Weber, D. (2010), Quellen zur Geschichte des Partherreiches, vols. 3, Göttingen. Hammond, M. (1934): Corbulo and Nero's Eastern Policy, HSCPh 45: 81-104.

Heil, M. (1997), Die orientalische Außenpolitik des Kaisers Nero, München.

Henderson, B.W. (1901), The Chronology of the Wars in Armenia, A.D. 51-63, CR 15: 159-163, $204-$ $-213,266-274$.

Kahrstedt, U. (1950), Artabanos III. und seine Erben, Bern.

Karras-Klapproth, M. (1988), Prosopographische Studien zur Geschichte des Partherreiches auf der Grundlage antiker literarischer Überlieferung, Bonn. 
Krämer, K. (1973), Zum Freundschaftsvertrag zwischen Rom und Parthien unter Augustus, Klio 55: $247-248$.

Lerouge, Ch. (2007), L'image des Parthes dans le monde greco-romain. Du début du I'r siecle av. J.-C. Jusqu'a la fin du Haut-Empire romain, Stuttgart.

Luther, A. (2010), Zum Orientfeldzug des Gaius Caesar, Gymnasium 117: 103-127.

Malitz, J. (1984), Caesars Partherkrieg, Historia 33: 21-59.

Mehl, A. (1979), Kaiser Claudius und der Feldherr Corbulo bei Tacitus und Cassius Dio, Hermes 107: 220-239.

Meulder, M. (1993), L. Caesennius Paetus, un avatar du guerrier impie chez Tacite (Ann. XV, 7-8)?, Latomus 52: 98-104.

Momigliano, A. (1975), Corbulone e la politica romana verso i Parti, in: A. Momigliano, Quinto contributo alla storia, degli studi classici e del mondo antico, vol. 1, Roma: 649-656.

Noè, E. (1992), Province, Parti e guerra civile: il caso di Labieno, Athenaeum 85: 409-436.

Olbrycht, M.J. (1997), Vardanes contra Gotarzes II. - Einige Überlegungen zur Geschichte des Partherreiches ca. 40-51 n. Chr., Folia Orientalia 33: 81-100.

Olbrycht, M.J. (1998a), Das Arsakidenreich zwischen der mediterranen Welt und Innerasien, Bemerkungen zur politischen Strategie der Arsakiden von Vologases I. bis zum Herrschaftsantritt des Vologases III. (50-147 n. Chr.), Electrum 2: 123-159.

Olbrycht, M.J. (1998b), Parthia et ulteriores gentes. Die politische Bezihungen zwischen dem arsakidischen Iran und den Nomaden der eurasiatischen Steppen, München.

Olbrycht, M.J. (2012), The Political-Military Strategy of Artabanos/Ardawān II in 34-37, Anabasis. Studia Classica et Orientalia 3: 160-178.

Olbrycht, M.J. (2014), The Genealogy of Artabanos II (AD 8/9-39/40), King of Parthia, Miscellanea Anthropologica et Sociologica 15 (3): 92-97.

Olbrycht, M.J. (2016), Vologases I, Pacoros II and Artabanos III: Coins and Parthian History, Iranica Antiqua 51: 215-233.

Oller Guzmán, J. (2014), Rex Armeniis datus? Nero, Parthia and the Armenian Question, in: B. Antela-Bernardez, J. Vidal (eds.), Central Asia in Antiquity: Interdisciplinary Approaches, Oxford: 85-97.

Oltramare, A. (1938), Auguste et les Parthes, REL 16: 121-138.

Pani, M. (1972), Roma e i re d'Oriente da Augusto a Tiberio (Cappadocia, Armenia, Media Atropatene), Bari.

Potter, D.S. (1991), The Inscription on the Bronze Herakles from Mesene: Vologeses IV's War with Rome and the Date of Tacitus' Annales, ZPE 88: 277-290.

Questa, C. (1960), Studi sulle fonti degli Annales di Tacito, Roma.

Romer, F.E. (1974), G. and L. Caesar in the East, Ph.D Thesis, Dept. of Classics, Stanford University (Calif.).

Romer, F.E. (1979), Gaius Caesar's Military Diplomacy in the East, TAPA 109: 199-214.

Salvo, D. (2008/2009), La crisi romano-partica del 54-63 d.C.: la prospettiva romana nel resoconto di Tacito, öpuo - Ricerche di Storia Antica 1: 226-239.

Schippmann, K. (1980), Grundzüge der parthischen Geschichte, Darmstadt.

Schottky, M. (1991), Parther, Meder und Hyrkanier. Eine Untersuchung der dynastischen und geographischen Verflechtungen im Iran des 1. Jhs. n. Chr., AMI 24: 61-134.

Schulde, J.M. (2015), The Early Parthian Policy of Augustus, Anabasis. Studia Classica et Orientalia 6: $139-156$.

Schur, W. (1923), Die Orientpolitik des Kaisers Nero, Leipzig.

Schur, W. (1925), Untersuchungen zur Geschichte der Kriege Corbulos, Klio 19: 75-96.

Schur, W. (1926), Zur neronischen Orientpolitik, Klio 20: 215-222.

Sellwood, D. (1980), An Introduction to the Coinage of Parthia, $2^{\text {nd }}$ ed., London.

Shayegan, M.R. (2011), Arsacids and Sasanians: Political Ideology in Post-Hellenistic and Late Antique Persia, Cambridge.

Shenk, D. (2007), The Immortal Game: A History of Chess, or How 32 Carved Pieces on a Board Illuminated Our Understanding of War, Art, Science, and the Human Brain, New York. 
Sinisi, F. (2012), Sylloge Nummorum Parthicorum: New York - Paris - London - Vienna - Teheran Berlin, vol. VII: Vologases I. - Pacorus II, Wien.

Syme, R. (1958), Tacitus, vols. 2, Oxford.

Syme, R. (1968), The Ummidii, Historia 17: 72-105.

Syme, R. (1970), Domitius Corbulo, JRS 60: 27-39.

Timpe, D. (1975), Zur augusteischen Partherpolitik zwischen 30 und 20 v. Chr., Würzburger Jahrbücher für die Altertumswissenschaft 1: 155-169.

Traina, G. (1996), Sulla fortuna di Domizio Corbulone, in: C. Stella, A. Valvo (a cura di), Studi in onore di Albino Garzetti, Brescia: 491-503.

Traina, G. (2010), La resa di Roma. Battaglia a Carre, 9 giugno 53 a.C., Roma-Bari.

Verstandig, A. (2001), Histoire de l'Empire Parthe (-250/227), Belgium.

Vervaet, F.J. (1999a), Tacitus, Domitius Corbulo and Traianus' Bellum Parthicum, L'Antiquité Classique 68: 289-297.

Vervaet, F.J. (1999b), CIL IX 3426: A New Light on Corbulo's Career, with Special Reference to his Official Mandate in the East from AD 55 to AD 63, Latomus 58: 574-599.

Vervaet, F.J. (2002), Caesennius Sospes, the Neronian Wars in Armenia and Tacitus View on the Problem of Roman Foreign Policy in the East: A Reassessment, Mediterraneo Antico 5: 283-318.

Wheeler, E.L. (1997), The Chronology of Corbulo in Armenia, Klio 79: 383-397.

Wheeler, E.L. (2002), Roman Treatises with Parthia: Völkerrecht or Power Politics?, in: P. Freeman, J. Bennett, Z.T. Fiema, B. Hoffmann (eds.), Limes XVIII. Proceedings of the XVIII ${ }^{\text {th }}$ International Congress of Roman Frontier Studies held in Amman, Jordan (September 2000), Oxford: 281-286.

Wiesehöfer, J. (1994), Das antike Persien. Von 550 v. Chr. bis 650 n. Chr., München-Zürich.

Wiesehöfer, J. (1998), Das Partherreich und seine Zeugnisse. Beiträge des internationalen Colloquiums, Eutin (27.-30. Juni 1996), Stuttgart.

Wiesehöfer, J. (2010), Augustus und die Parther, in: R. Aßkamp, T. Esch (hrsg.), Imperium. Varus und seine Zeit, Münster: 187-195.

Wijlick, H. van (2015), Constructing Alliances: A New Perspective on Mark Antony's Parthian Campaign of 36 BC, Journal of Ancient Civilizations 30: 65-71.

Wolski, J. (1993), L'Empire des Arsacides, Leuven.

Zetzel J.E.G. (1970), New Light on Gaius Caesar's Eastern Campaign, GRBS 11: 259-266.

Ziegler, K.-H. (1964), Die Beziehungen zwischen Rom und dem Partherreich. Ein Beitrag zur Geschichte des Völkerrechts, Wiesbaden. 